\title{
COMPARISON OF LAPAROSCOPIC TOTAL GASTRECTOMY AND LAPAROTOMIC TOTAL GASTRECTOMY FOR GASTRIC CANCER
}

\author{
Comparação entre a gastrectomia total laparoscópica e a gastrectomia total laparotômica para o câncer gástrico
}

Carlos Alexandre Garção RAMAGEM ${ }^{2}$, Marcelo LINHARES ${ }^{3}$. Croider Franco LACERDA ${ }^{1}$, Paulo Anderson BERTULUCCI ${ }^{1}$,Durval WONRATH ${ }^{1}$, Antônio Talvane Torres de OLIVEIRA $^{1}$

From the ${ }^{1}$ Departamento de Cirurgia Oncológica do Trato Gastrointestinal Superior, Hospital do Câncer de Barretos, Barretos, São Paulo, SP; 2Departamento de Cirurgia Oncológica do Trato Gastrointestinal Superior, Hospital do Câncer de Barretos, Unidade de Porto Velho, Rondônia RO; ${ }^{3}$ Disciplina de Gastroenterologia Cirúrgica, Departamento de Cirurgia, Universidade Federal de São Paulo/ Escola Paulista de Medicina, São Paulo, SP ('Department of Oncological Surgery of the Upper Gastrointestinal Tract, Barretos Cancer Hospital, Barretos, São Paulo, $\mathrm{SP} ;{ }^{2}$ Department of Oncological Surgery of the Gastrointestinal Tract, Barretos Cancer Hospital, Porto Velho Unit, Rondônia, RO; ${ }^{3}$ Discipline of Surgical Gastroenterology, Department of Surgery, Federal University of São Paulo/Escola Paulista de Medicina, São Paulo, SP), Brazil

HEADINGS - Total gastrectomy. Laparoscopic gastrectomy. Gastriccancer. D2 lymphadenectomy.

\section{Correspondence:}

Carlos Alexandre Garção Ramagem

Email: carlosramagem@globo.com

Financial source: none

Conflicts of interest: none

Received for publication: 12/08/2014 Accepted for publication: 09/12/2014

DESCRTORES - Gastrectomia total. Gastrectomia videolaparoscópica. Câncer gástrico. Linfadenectomia D2.
ABSTRACT - Background: The use of laparoscopy for the treatment of gastric cancer suffered some resistance among surgeons around the world, gaining strength in the past decade. However, its oncological safety and technical feasibility remain controversial. Aim: To describe the results from the clinical and anatomopathological point of view in the comparative evaluation between the surgical videolaparoscopic and laparotomic treatments of total gastrectomy with linphadenectomy at D2, resection R0. Method: Retrospective analyses and comparison data from patients submitted to total gastrectomy with D2 linphadenectomy at a sole institution. The data of 111 patients showed that $64(57,7 \%)$ have been submitted to laparotomic gastrectomy and 47 (42,3\%) to gastrectomy entirely performed through videolaparoscopy. All variables related to the surgery, post-operative follow-up and anatomopathologic findings have been evaluated. Results: Among the studied variables, videolaparoscopy has shown a shorter surgical time and a more premature period for the introduction of oral and enteral nourishment than the open surgery. As to the amount of dissected limph nodes, there has been a significant difference towards laparotomy with $p=0,014$, but the average dissected limph nodes in both groups exceed 25 nodes as recommended by the JAGC. Was not found a significant difference between the studied groups as to age, ASA, type of surgery, need for blood transfusion, stage of the disease, Bormann classification, degree of differentiation, damage of the margins, further complications and death. Conclusion: The total gastrectomy with D2 lymphadenectomy performed by laparoscopy presented the same benefits known of laparotomy and with the advantages already established of minimally invasive surgery. It was done with less surgical time, less time for re-introduction of the oral and enteral diets and lower hospitalization time compared to laparotomy, without increasing postoperative complications.

RESUMO - Racional: A utilização da videolaparoscopia para o tratamento das neoplasia gástricas sofreu certa resistência entre os cirurgiões ao redor do mundo, ganhando força na década passada. Porém, sua segurança oncológica e viabilidade técnica continuam controversas. Objetivo: Demonstrar os resultados do ponto de vista clínico e anatomopatológico na avaliação comparativa entre o tratamento cirúrgico videolaparoscópico e laparotômico da gastrectomia total com linfadenectomia a D2, ressecção R0. Métodos: Estudo retrospectivo dos dados dos prontuários dos pacientes submetidos à gastrectomia total com lindadenectomia a D2, em uma única instituição. Dos 111 prontuários, 64 (57,7\%) foram submetidos à gastrectomia laparotômica e $47(42,3 \%)$ à gastrectomia totalmente vídeolaparoscópica. Foram avaliadas variáveis relacionadas ao ato cirúrgico, a evolução pós-operatória e a achados anatomopatológicos. Resultados: A técnica videolaparoscópica demonstrou tempo cirúrgico menor e período para re-introdução alimentar oral e enteral mais precoce que a operação laparotômica. Quanto ao número de linfonodos dissecados, houve diferença significante a favor da laparotômica $(p=0,014)$; porém, a média de linfonodos dissecados em ambos os grupos ultrapassou os 25 preconizados pela JAGC. Não foi encontrada diferença significante entre os grupos estudados no que diz respeito à idade, gênero, ASA, tipo de operação, necessidade de hemotransfusão, estadiamento, classificação de Bormann, grau de diferenciação, comprometimento de margens, complicações e óbito. Conclusões: A gastrectomia total com linfadenectomia a D2 realizada por videolaparoscopia apresenta os mesmos benefícios conhecidos da cirurgia laparotômica e com as vantagens já estabelecidas da cirurgia minimamente invasiva. Ela apresentou menor tempo cirúrgico, menor tempo para a re-introdução das dietas oral e enteral e tempo de alta menor em relação à laparotômica, sem aumentar as complicações pós-operatórias.

\section{INTRODUCTION}

T he advance of laparoscopic surgery for the treatment of cancer began with the colorectal surgeries ${ }^{10}$ in the 90 s, showing similar results from the oncological standpoint to open surgery. Due to technical difficulties, longer learning curve and need for a more advanced technological arsenal, the use of laparoscopy for the treatment of gastric cancer underwent some resistance among surgeons around the world, gaining momentum in the past decade. But its oncological safety and technical feasibility remains controversial.

The history of laparoscopic gastric resection began in Singapore, when Goh et al. (1992) performed the first distal gastric resection with Billroth II reconstruction in a 
76-year-patient with chronic gastric ulcer ${ }^{8}$. But it was Kitano et al. (1994) who published the first subtotal laparoscopic gastrectomy with Billlroth I reconstruction for the treatment of distal gastric cancer ${ }^{14}$.

The video-assisted lymphadenectomy was recommended by several authors ${ }^{19}$, opening the opportunity for the totally laparoscopic operation in the future.

Several authors have published studies making the comparison between open methods and/or video-assisted and the surgery performed totally by laparoscopy. Kodera et al. (2010) published a meta-analysis for this purpose. The study showed that laparoscopic gastrectomy with D2 can be performed safely, with less blood loss and longer surgical time. The number of resected lymph nodes was similar in both techniques ${ }^{15}$. Ohtani et al. (2011) published another metaanalysis describing five randomized clinical trials totaling 326 patients. There was no significant difference in relation to the time of return to oral diet, the tumor recurrence or mortality, as well as to the estimated blood loss, the length of hospital stay, the frequency of analgesic use, and the further complications, all favoring the laparoscopic treatment. However, the operative time was significantly higher and the number of resected lymph nodes significantly lower in videoassisted surgery ${ }^{20}$. Orsenigo et al. (2011) compared 109 patients who underwent laparoscopic gastrectomy with 269 patients undergoing traditional open gastrectomy. The results of this study demonstrated that the surgical time and the morbidity were significantly greater in video-assisted surgeries, while the distance from the proximal margin was significantly lower in open surgery. The average of lymph node resection was higher in patients undergoing video laparoscopy $(p=0.002)$, contrary to the previous study. As to survival rate, there was no significant difference between the groups. The authors concluded that the extended lymphadenectomy for gastric cancer is feasible and safe despite the high morbidity ${ }^{21}$.

There are few published studies in the literature comparing the results between totally laparoscopic total gastrectomy with intracavitary esophagojejunal anastomosis to the open total gastrectomy for the treatment of gastric cancer. In Brazil, no comparative study between laparoscopic operation and laparotomy for the treatment of gastric cancer was found.

The aim of this article was to demonstrate the differences between laparoscopic and laparotomic approach for the treatment of gastric cancer in our country, comparing variables related to anthropometric parameters, surgical performance, pathological results and complications.

\section{METHODS}

\section{Characteristics of the sample}

In this present study the files of patients undergoing total gastrectomy with D2 lymphadenectomy, curative, R0 resection at Barretos Cancer Hospital, Pio XII Foundation, were analyzed in a retrospective way between August, 2009 and April, 2013. The inclusion criteria covered patients with histologically proven gastric adenocarcinoma, above 18 years of age, of both genders, and patients classified as ASA I and II according to the American Association of Anesthesiology ${ }^{1}$. Patients undergoing proximal or distal subtotal gastrectomy, D0 or D1 lymphadenectomy, non-radical resection of the R1 and R2 types, ASA III or IV patients, stage IV patients, and patients that underwent previous gastric surgery or any neoadjuvant cancer therapy were excluded.

In the sample analysis for the assessment, 111 records were studied. Sixty-four of them (57.7\%) were from patients undergoing total open gastrectomy with $\mathrm{D} 2$ lymphadenectomy (OTG) and 47 of them (42.3\%) of patient undergoing totally laparoscopic gastrectomy with D2 lymphadenectomy (TLTG).

\section{Statistical analysis}

For the qualitative variables, the statistical data studied were the absolute frequencies ( $n$ ) and the relative frequencies (\%). For the quantitative variables, the average and the median were used as summary measures and the standard deviation, minimum and maximum, were used to point variability. For the qualitative variables, personal tests of Chi-square and Fisher's exact test were used. For the quantitative variables, Student's t-distribution and the Mann-Whitney tests were used. In the tests that were used, the level of statistical significance for rejecting the null hypothesis stood at 0.05 or $5 \%(\alpha \leq 0.05)$.

RESULTS

When comparing the laparoscopic and the open techniques, no significant difference was found regarding gender, ASA, the incidence of elective and emergency surgery in the association of resected organs. There was no significant difference regarding the need for blood transfusion in the first $48 \mathrm{~h}$ when comparing the two groups. In the analysis of the anatomical and pathological findings, there was no significant difference when comparing patients undergoing OTG and TLTG as to staging, Bormann classification, degree of cell differentiation, compromised margins, and Lauren classification. In the assessment of the tumor localization in the surgical specimen, no significant difference in tumor localization was found when the two groups were compared. No significant difference was evidenced when comparing the two groups as to postoperative outcome regarding early surgical complications, the reason for reoperation, the cause of rehospitalization, and deaths (Table 1).

In order to evaluate the quantitative variables, they were grouped into a single table for better understanding, where the data in terms of absolute number, average, standard deviation, and allocated to the laparotomy and laparoscopy groups are displayed.

When comparing the results for each analyzed group, no significant difference regarding age, BMI, number of compromised lymph nodes, and number of blood products used was found. Significant differences were found in operative time, with an average of $255.5 \mathrm{~min}$ in open surgery and $216.3 \mathrm{~min}$ in laparoscopy $(p=0.001)$. When the number of dissected lymph nodes were assessed in the group where all cases of OTG were included and compared to TLTG, the average number of dissected lymph nodes in the OTG was 35.1 lymph nodes/patient, and 29.1 nodes in the TLTG with a significant $p(p=0.014)$.

The reintroduction of the oral diet was approximately on the 3.9 postoperative day in the OTG and 2.3 in the TLTG, with a significant $p(p=0.001)$. As to the beginning of the enteral diet, the average was 2.4 postoperative day in the OTG and 1.58 in the TLTG, with a significant $p(p=0.002)$. The duration of hospitalization was statistically shorter in the TLTG with an average of 7.36 days in the OTG and 5.8 days in the TLTG with a significant $p(p=0.001)$

\section{DISCUSSION}

Since the first laparoscopic gastrectomy for the treatment of gastric cancer performed by Kitano in $1994^{14}$, this technical approach has been progressively evolving and becoming more popular among surgeons worldwide. The use of laparoscopy has brought advantages such as shorter hospital stay, less need for blood transfusion, less need for analgesics, early reintroduction of food, shorter postoperative ileum, and better cosmetic results. But there is still controversy in its application, mainly in advanced gastric cancer regarding the safety and oncologic efficacy. Variables 
TABLE 1 - Distribution of variables divided in the laparotomy and laparoscopy groups

\begin{tabular}{|c|c|c|c|c|c|}
\hline Variable & Category & OTG & TLTG & Total & $\mathrm{P}$ \\
\hline \multirow{2}{*}{ Gender } & Male & $43(55,8 \%)$ & $34(44,2 \%)$ & 77 (100,0\%) & \multirow{2}{*}{0,561} \\
\hline & Female & $21(61,8 \%)$ & $13(38,2 \%)$ & $34100,0 \%$ & \\
\hline \multirow{2}{*}{ ASA } & I & $22(64,7 \%)$ & $12(35,3 \%)$ & $34(100,0 \%)$ & \multirow{2}{*}{0,318} \\
\hline & II & $42(54,5 \%)$ & $35(45,5 \%)$ & $77(69,4 \%)$ & \\
\hline \multirow{3}{*}{$\begin{array}{l}\text { Type of } \\
\text { surgery }\end{array}$} & Elective & $64(58,7 \%)$ & $45(41,3 \%)$ & $109(100,0 \%)$ & \multirow{2}{*}{0,177} \\
\hline & Urgent & $0(0,0 \%)$ & $2(100,0 \%)$ & $2(100,0 \%)$ & \\
\hline & Spleen & $3(50,0 \%)$ & $3(50,0 \%)$ & $6(100,0 \%)$ & \multirow{5}{*}{ - } \\
\hline \multirow{4}{*}{$\begin{array}{l}\text { Extended } \\
\text { resection }\end{array}$} & Esophagus & $0(0,0 \%)$ & $1(100,0 \%)$ & $1(100,0 \%)$ & \\
\hline & Liver & $0(0,0 \%)$ & $1(100,0 \%)$ & $1(100,0 \%)$ & \\
\hline & Pancreas & $1(100,0 \%)$ & $0(0,0 \%)$ & $1(100,0 \%)$ & \\
\hline & Gallbladder & $14(51,9 \%)$ & $13(48,1 \%)$ & $27(100,0 \%)$ & \\
\hline \multirow{2}{*}{$\begin{array}{l}\text { Blood } \\
\text { transfusion }\end{array}$} & No & $47(54,0 \%)$ & $40(46,0 \%)$ & $87(100,0 \%)$ & \multirow[b]{2}{*}{0,14} \\
\hline & Yes & 17 (70,8\%) & $7(29,2 \%)$ & $24(100,0 \%)$ & \\
\hline \multirow{3}{*}{ TNM Staging } & I & $21(60 \%)$ & $14(40,0 \%)$ & $35(100,0 \%)$ & \multirow{3}{*}{0,926} \\
\hline & II & $16(55,2 \%)$ & $13(44,8 \%)$ & $29(100,0 \%)$ & \\
\hline & III & $27(57,4 \%)$ & $20(42,6 \%)$ & 47 (100,0\%) & \\
\hline \multirow{4}{*}{$\begin{array}{c}\text { Bormann } \\
\text { Classification }\end{array}$} & I & $0(0,0 \%)$ & $2(100,0 \%)$ & $2(100,0 \%)$ & \multirow{4}{*}{0,13} \\
\hline & II & $3(37,5 \%)$ & $5(62,5 \%)$ & $8(100,0 \%)$ & \\
\hline & III & $38(61,3 \%)$ & $24(38,6 \%)$ & $62(100,0 \%)$ & \\
\hline & IV & $2(33,3 \%)$ & $4(66,7 \%)$ & $6(100,0 \%)$ & \\
\hline \multirow{3}{*}{ Differentiation } & Degree I & $4(66,7 \%)$ & $2(33,3 \%)$ & $6(100,0 \%)$ & \multirow{3}{*}{0,604} \\
\hline & Degree II & $16(48,5 \%)$ & $17(51,5 \%)$ & $33(100,0 \%)$ & \\
\hline & Degree III & $41(59,4 \%)$ & $28(40,6 \%)$ & $69(100,0 \%)$ & \\
\hline \multirow{3}{*}{ Margin } & Free & $61(56,5 \%)$ & $47(43,5 \%)$ & $108(100,0 \%)$ & \multirow{3}{*}{0,510} \\
\hline & Exiguous & $1(100,0 \%)$ & $0(0,0 \%)$ & $1(100,0 \%)$ & \\
\hline & Commited & $2(100,0 \%)$ & $0(0,0 \%)$ & $2(100,0 \%)$ & \\
\hline \multirow{6}{*}{$\begin{array}{l}\text { Location of } \\
\text { the tumor in } \\
\text { the surgical } \\
\text { specimen }\end{array}$} & Cardia & $4(57,1 \%)$ & $3(42,9 \%)$ & $7(100,0 \%)$ & \\
\hline & Fundus & $2(66,7 \%)$ & $1(33,3 \%)$ & $3(100,0 \%)$ & \\
\hline & Body & $25(52,1 \%)$ & $23(47,9 \%)$ & $48(100,0 \%)$ & \\
\hline & Antrum & $28(63,6 \%)$ & $16(36,4 \%)$ & $44(100,0 \%)$ & 0,900 \\
\hline & Pylorus & $3(50 \%)$ & $3(50 \%)$ & $6(100,0 \%)$ & \\
\hline & Linite & $2(66,7 \%)$ & $1(33,3 \%)$ & $3(100,0 \%)$ & \\
\hline & Diffuse & $21(44,7 \%)$ & $26(55,3 \%)$ & 47 (100,0\%) & \\
\hline S & Intestinal & $32(62,7 \%)$ & $19(37,3 \%)$ & 51 (100,0\%) & 0,022 \\
\hline & Mixed & $11(84,6 \%)$ & $2(15,4 \%)$ & 13 (100,0\%) & \\
\hline & Early bridle & $2(100,0 \%)$ & $0(0,0 \%)$ & $2(100,0 \%)$ & \\
\hline & $\begin{array}{l}\text { Pleural } \\
\text { effusion }\end{array}$ & $1(100,0 \%)$ & $0(0,0 \%)$ & $1(100,0 \%)$ & \\
\hline & Fistula & $3(75 \%)$ & $1(25 \%)$ & $4(100,0 \%)$ & \\
\hline & Phlebitis & $2(100,0 \%)$ & $0(0,0 \%)$ & $2(100,0 \%)$ & \\
\hline Complications & Hemorrhage & $1(50,0 \%)$ & $1(50,0 \%)$ & $2(100,0 \%)$ & 0,316 \\
\hline & $\begin{array}{l}\text { Postoperative } \\
\text { wound } \\
\text { Infection }\end{array}$ & $1(100,0 \%)$ & $0(0,0 \%)$ & $1(100,0 \%)$ & \\
\hline & UninaryInfection & $2(100,0 \%)$ & $0(0,0 \%)$ & $2(100,0 \%)$ & \\
\hline & Pneumonia & $1(33,3 \%)$ & $2(66,7 \%)$ & $3(100,0 \%)$ & \\
\hline Reoperation & No & $60(57,7 \%)$ & $44(42,3 \%)$ & $104(100,0 \%)$ & \\
\hline кеoperation & Yes & $4(57,1 \%)$ & $3(42,9 \%)$ & $7(100,0 \%)$ & 0,635 \\
\hline & Bleeding & $1(100,0 \%)$ & $0(0,0 \%)$ & $1(100,0 \%)$ & \\
\hline & $\begin{array}{l}\text { Injury of } \\
\text { spleen }\end{array}$ & $0(0,0 \%)$ & $1(100,0 \%)$ & $1(100,0 \%)$ & \\
\hline reoperation & $\begin{array}{c}\text { Internal } \\
\text { hernia and/or } \\
\text { bridle }\end{array}$ & $2(50,0 \%)$ & $2(50,0 \%)$ & $4(100,0 \%)$ & 1,000 \\
\hline & Eventration & $1(100,0 \%)$ & $0(0,0 \%)$ & $1(100,0 \%)$ & \\
\hline Rehospitalizati & Yes & $3(60,0 \%)$ & $2(40,0 \%)$ & $5(100,0 \%)$ & 1,000 \\
\hline Renospitalizauc & No & $61(57,5 \%)$ & $45(42,5 \%)$ & $106(100,0 \%)$ & 1,000 \\
\hline & No & $62(57,4 \%)$ & $46(42,6 \%)$ & $108(100,0 \%)$ & \\
\hline & Yes & $2(66,7 \%)$ & $1(33,3 \%)$ & $3(100,0 \%)$ & U \\
\hline
\end{tabular}

laparoscopic gastrectomy with D2 lymphadenectomy

TABLE 2 - Demonstration of the behavior of the quantitative variables that were studied and distributed in laparotomy and laparoscopic groups

\begin{tabular}{|c|c|c|c|c|c|c|}
\hline Variables & Procedure & $\mathrm{N}$ & Average & Median & $\begin{array}{l}\text { Standard } \\
\text { deviation }\end{array}$ & $p$ \\
\hline \multirow[b]{2}{*}{ Age } & OTG & 64 & 59,7 & 60,0 & 11,65 & \multirow[b]{2}{*}{0,233} \\
\hline & TLTG & 47 & 57,8 & 58,0 & 10,53 & \\
\hline \multirow[b]{2}{*}{ BMI } & OTG & 63 & 23,8 & 32,1 & 4,04 & \multirow[b]{2}{*}{0,448} \\
\hline & TLTG & 45 & 23,2 & 22,3 & 4,36 & \\
\hline \multirow{2}{*}{ Surgical time } & OTG & 64 & 255,5 & 252,5 & 54,63 & \multirow{2}{*}{0,001} \\
\hline & TLTG & 47 & 216,3 & 220,0 & 22,66 & \\
\hline \multirow{2}{*}{$\begin{array}{l}\text { Dissected lymph } \\
\text { nodes }\end{array}$} & OTG & 64 & 35,2 & 33,0 & 12,70 & \multirow{2}{*}{0.014} \\
\hline & TLTG & 47 & 29,1 & 28,0 & 12,66 & \\
\hline \multirow{2}{*}{$\begin{array}{l}\text { Compromised } \\
\text { lymph nodes }\end{array}$} & OTG & 64 & 5,5 & 1,0 & 9,28 & \multirow{2}{*}{0,832} \\
\hline & TLTG & 47 & 4,4 & 1,0 & 6,74 & \\
\hline \multirow{2}{*}{$\begin{array}{l}\text { Number of blood } \\
\text { products }\end{array}$} & OTG & 64 & 0,5 & 0,0 & 0,94 & \multirow{2}{*}{0,127} \\
\hline & TLTG & 47 & 0,3 & 0,0 & 0,88 & \\
\hline \multirow{2}{*}{$\begin{array}{l}\text { Beginning of oral } \\
\text { diet }\end{array}$} & OTG & 62 & 3,9 & 4,0 & 1,47 & \multirow{2}{*}{0,001} \\
\hline & TLTG & 46 & 2,3 & 2,0 & 1,07 & \\
\hline \multirow{2}{*}{$\begin{array}{l}\text { Beginning of } \\
\text { enteral diet }\end{array}$} & OTG & 37 & 2,4 & 2 & 1,18 & \multirow{2}{*}{0,002} \\
\hline & TLTG & 36 & 1,58 & 1 & 0,69 & \\
\hline \multirow{2}{*}{ Hospital discharge } & OTG & 61 & 7,36 & 6 & 4,01 & \multirow{2}{*}{0,001} \\
\hline & TLTG & 46 & 5,8 & 5 & 2,18 & \\
\hline
\end{tabular}

OTG=open total gastrectomy; TLTG=total gastrectomy; $N=$ number of cases; $\mathrm{BMI}=$ body mass index such as number of dissected lymph nodes, complications, and recurrences linked to the method are issues quite discussed in the literature.

There are few published studies in the literature comparing the OTG with totally laparoscopic TLTG. The systematic review and meta-analysis published in 2012 shows that in eight published studies, only four of them included laparoscopic surgery for advanced gastric cancer, and of these, the realization of D2 lymphadenectomy occurred in only three series ${ }^{9}$.

The aim of this study was to demonstrate in our midst if the performance of the totally laparoscopic total gastrectomy with D2 lymphadenectomy surgery has the same immediate results of the open gastrectomy.

In the sample no significant difference was found regarding age, gender, BMI, anesthetic risk ASA, staging, and type of surgery performed. Also no significant difference was found in the location of the lesions, Bormann classification, compromised margins, or degree of cell differentiation.

As to the resection of the organs associated to the removed stomach with neoplasia, which in this study occurred in $32.4 \%$ of the cases, there was no difference between groups $(p=1.00)$, which meets the literature ${ }^{26,16}$.

Series of published reports have addressed the estimated blood loss during the operation. In general, the blood loss during the laparoscopic procedure was significantly lower than during the open procedures $5,6,9,21,26,27,29$. In this study there was no significant difference as to the average of blood units received in both groups $(p=0.127)$. Some authors, however, question the external interference that may have influenced these results; they also state that the heterogeneity of the groups may have influenced the results, since the vast majority was studies without randomization and performed retrospectively?

As to the surgical time of laparoscopic surgeries, the learning curve is part of a natural process. The literature data are conflicting, presenting papers in which the surgical time is significantly higher in the laparoscopic surgery and, in others, the difference between groups was not significant $6,15,20,21,29$.

The first studies showed disadvantages of laparoscopy as to operative, also considering the risks of prolonged pneumoperitoneum ${ }^{29}$. In this paper, the surgical laparoscopic procedure time was significantly lower in TLTG with $p=0.0001$. Another limiting factor was the esophagojejunal anastomosis, requiring great skill of the surgeon ${ }^{13}$. The technique used for the intracavity esophagojejunal anastomosis performed here follows the standardization developed by the Barretos Cancer Hospital staff known as "reverse warhead"16. It is believed that the longer surgical time in the laparoscopic route of access observed in most published series is due mainly to the recent indication of the technique as a surgical treatment of gastric cancer. The rapid technological advancement, coupled with the development of higher resolution optical imaging equipment and surgical instruments increasingly modern, as well as the increasing experience gained by staffs around the world will allow the increasingly rapid realization of the laparoscopic gastric resection surgery in a short time.

Shinohara et al. (2013) published a retrospective study of 10 years of experience in laparoscopic surgery for resection of gastric cancer comparing the outcomes between laparoscopic gastrectomy $(n=186)$ and open gastrectomy $(n=150)^{26}$. Concerning the reintroduction of oral diet, the average of days for laparoscopic was 3.4 days and 5.7 days for open surgery $(p<0.001)$. Kim et al. (2013) compared 139 totally laparoscopic total gastrectomy operations with 207 patients undergoing laparotomy, noting that the return of oral diet was significantly faster in laparoscopic surgery $(p=0.018)^{13}$, corroborating the data from many studies in 
the literature ${ }^{6,20,26}$. On the other hand, Jeong et al. (2013) in their series found no significant difference with regard to the time of return to oral diet ${ }^{12}$. In this study, the time for the return of the oral diet had an average of 3.90 days in the OTG, compared to 2.32 days in TLTG, showing a statistically significant difference between groups in favor of laparoscopic surgery $(p=0.001)$. As for the resumption of enteral diet, there was also significant difference between groups.

The average number of days needed for enteral nutrition was 2.40 days in the OTG and 1.58 days in the TLTG $(p=0.002)$, showing a tendency of short return of the bowel activity in cases of laparoscopic surgery.

Shinohara et al. (2013) in their publication in which only stages $\mathrm{T} 2, \mathrm{~T} 3$, and $\mathrm{T} 4$ were included, the surgeries performed were curative and with D2 lymphadenectomy. The video-assisted surgeries were excluded. The average of postoperative hospital stay was 16.3 days for laparoscopic and 24.3 days for open surgery $(p<0.001)$. These authors claim that, despite the outcome in favor of minimally invasive surgery, the number of days of hospitalization in both groups is quite high. The authors' justification for this is due to the care of the institution, where patients often receive the first dose of chemotherapy still in the same hospitalization ${ }^{26}$. Haverkamp et al. (2013), in a meta-analysis of 698 cases, found an average length of postoperative hospital stay of approximately four days of difference in favor of laparoscopy, respectively 14.1 and 18.1 days $(p<0.001)^{9}$. In another sample, Wei et al. (2011) demonstrated a shorter hospital stay of patients undergoing laparoscopic gastrectomy compared to laparotomy $(p<0.0001)^{29}$. In similar studies comparing totally laparoscopic to laparotomic operations, Kim et al. (2013) and Chen et al. (2013) concluded that the time of postoperative hospital stay was significantly lower in laparoscopic surgery, with $p<0.001$ and $p<0.05$, respectively ${ }^{5,13}$. On the other hand, Jeong et al. (2013) found no significant difference between the groups with regard to the time of hospital discharge $(p=0.072)^{12}$. This study corroborates the data of most studies in the literature, obtaining a shorter hospital stay for the laparoscopic group, with statistically significant difference $(p=0,001)$.

Cui at al. (2012) published the results of 209 patients who underwent open and laparoscopic gastrectomy with D2 lymphadenectomy and measured the number of removed lymph nodes in surgical specimens. The average number of lymph nodes was $26.1 \pm 11$ for laparoscopy and $24.2 \pm 9.3$ for open surgery with a $p=0.233$. They concluded that there is no difference in terms of number of lymph nodes resected between the two techniques and that the D2 lymphadenectomy can be performed by means of laparoscopy safely and with the same radicalism of the open surgery ${ }^{7}$. Cianchi et al. (2013), in a cohort study comparing total laparoscopic and open surgery also demonstrated no statistically significant difference when assessed the number of dissected lymph nodes. The average of resected lymph nodes in laparoscopic and open surgery was respectively $29.4 \pm 1.6$ and $28.7 \pm 2.3^{6}$. Another study by Sato et al. (2012) evaluated the number of dissected lymph nodes in patients with early gastric cancer who underwent gastrectomy with D1 and D1 + lymphadenectomy, and patients with advanced gastric cancer with D2 lymphadenectomy. In cases of early gastric cancer significant differences were obtained $(p<0,01)$, whereas in cases of advanced gastric cancer no significant difference was found ${ }^{24}$. When comparing studies which evaluate patients undergoing total gastrectomy totally laparoscopic to total open gastrectomy, it can be observed: Kim et al. (2013) demonstrated a higher number of dissected lymph nodes in patients undergoing total laparoscopic gastrectomy compared to open surgery with a significant $p$ $(p=0.039)^{13}$. Shim et al. (2013) and Siani et al. (2012) found no significant difference between the groups ${ }^{25,27}$. In this study, a significant difference was found between the groups with a number of resected lymph nodes in the OTG greater than in TLTG $(p=0.014)$. Although the results of our study demonstrated a significant difference between the groups, with a lower number of lymph nodes in the group of patients undergoing laparoscopy, in both studies we may consider the number of dissected lymph nodes appropriate. There are few studies that demonstrate the safety of laparoscopic technique in the long run. Sato et al. (2012) and Wei et al. (2011) studied the survival rate for five years and found no significant differences between groups ${ }^{24,29}$. These data help us to believe that the answer to these questions regarding the oncological safety and security of the D2 lymphadenectomy in laparoscopic surgery may be favorable to the use of this technique in the surgical treatment of gastric cancer. Further randomized studies are needed to evaluate disease-free survival in the long term for us to complete the true safety of the laparoscopic method, as the number of dissected lymph nodes.

The overall percentage of complications described in this study was $15.3 \%$. $20.4 \%$ of complications in OTG and 8.5\% were found in TLTG, but no difference from a statistical standpoint $(p=0.31)$. In the stratified analysis we observed as main complications the digestive fistula (23.5\%), followed by pneumonia (17.6\%). A total of seven patients underwent reoperation within 30 days from the major surgery, four patients underwent OTG (6.2\%) and three patients underwent TLTG (6.4\%). There was no significant difference among the groups with $p=0.63$. Altogether there were three deaths, two in the OTG (3.1\%) and one in TLTG (2.1\%), totaling $2.7 \%$ of the patients in the sample, with no significant difference. Bo et al. (2009) evaluated the complications of laparoscopic gastrectomy in 302 patients and reported 21 cases of intra-abdominal bleeding, seven cases of duodenal fistula, two cases of pancreatitis among others. Six patients were reoperated and two of them died. The rate of postoperative complications was $7 \%$ and death occurred in $0.7 \%^{2}$. Park et al. (2012), in a multicenter retrospective study in 10 institutions, performed 239 gastrectomies between 1998 and 2005 in patients with advanced gastric cancer ${ }^{22}$. The total complication rate was $15.9 \%$. There were eight deaths. That result was similar to Sato et al. (2012), who found $25 \%$ of complications in laparoscopic and $23.7 \%$ in open gastrectomy, with no significant difference between the groups. The mortality rate was $0 \%$ in the laparoscopic and $1.7 \%$ in open surgery, also with no difference ${ }^{24}$. In the study by Siani et al (2013), the morbidity of fully laparoscopic gastrectomy was $16 \%$ compared to $32 \%$ of the open surgery, with $p<0.05$. There were no deaths in either group ${ }^{(27)}$.

\section{CONCLUSION}

The total gastrectomy with D2 lymphadenectomy performed by laparoscopy presents the same benefits known of the laparotomy surgery and with the advantages already established of minimally invasive surgery. She presented less surgical time, less time for the re-introduction of the oral and enteral diets and lower high time compared to laparotomy, without increasing postoperative complications.

\section{REFERENCES}

1. American Society of Anesthesiologists [Internet]. c1995 - 2013 [cited 2012 Jan 10]. Available from: http://www.asahq.org/.

2. Bo $T$, Zhihong $P$, Peiwu $Y$, Feng $Q$, Ziqiang W, Yan $S$, et al. General complications following laparoscopic-assisted gastrectomy and analysis of techniques to manage them. SurgEndosc. 2009 Aug;23(8):1860-5. 
3. Bormann R. Gerchwulstre des margens. In: Henke F, Lubarsch O. Handbuchspezpatholanat und histo. Berlin: Springer-Verlag; 1926. p. 864-71.

4. Brasil. Ministério da Saúde. Instituto Nacional de Câncer. Estatísticas do câncer: vigilância do câncer e fatores de risco [Internet]. C 19962007 [citado 2012 Abr 15]. Disponível em: http://www1.inca.gov. br/vigilancia/incidencia.html.

5. Chen K, Mou YP, Xu XW, Wang J, Yan JF, Zhang RC, et al. The clinical comparison of totally laparoscopic versus open total gastrectomy

6. Cianchi F, Qirici E, Trallori G, Macrì G, Indennitate G, Ortolani M, et al. Totally laparoscopic versus open gastrectomy for gastric cancer: a matched cohort study. J Laparoendosc Adv Surg Tech A. 2013 Feb;23(2):117-22.

7. Cui M, Xing JD, Yang W, Ma YY, Yao ZD, Zhang N, Su XQ. D2 dissection in laparoscopic and open gastrectomy for gastric cancer. World J Gastroenterol. 2012 Feb 28;18(8):833-9.

8. Goh P, Tekant Y, Kum CK, Isaac J, Shang NS. Totally intra-abdominal laparoscopic Billroth II gastrectomy. SurgEndosc. 1992 MayJun;6(3):160.

9. Haverkamp L, Weijs TJ, van der Sluis PC, van der Tweel I, Ruurda JP, van Hillegersberg R. Laparoscopic total gastrectomy versus open total gastrectomy for cancer: a systematic review and meta-analysis. SurgEndosc. 2013 May;27(5):1509-20.

10. Jacobs M, Verdeja JC, Goldstein MD. Minimally invasive colon resection (laparoscopic colectomy). SurgLaparoscEndosc. 1991;1(3):144-50.

11. Japanese Gastric Cancer Association. Japanese classification of gastric carcinoma: 3rd English edition. GastricCancer. 2011;14:101-12.

12. Jeong O, Jung MR, Kim GY, Kim HS, Ryu SY, Park YK. Comparison of short-term surgical outcomes between laparoscopic and open total gastrectomy for gastric carcinoma: case-control study using propensity score matching method. J Am CollSurg. 2013 Feb;216(2):184-91.

13. Kim HS, Kim BS, Lee IS, Lee S, Yook JH, Kim BS. Comparison of totally laparoscopic total gastrectomy and open total gastrectomy for gastric cancer. J Laparoendosc Adv Surg Tech A. 2013 Apr;23(4):323-31.

14. Kitano S, Iso Y, Moriyama M, Sugimachi K. Laparoscopy-assisted Billroth I gastrectomy. SurgLaparoscEndosc. 1994 Apr;4(2):146-8. Erratum in: SurgLaparoscEndosc. 2013 Oct;23(5):480.

15. Kodera Y, Fujiwara M, Ohashi N, Nakayama G, Koike M, Morita S, et al. Laparoscopic surgery for gastric cancer: a collective review with meta-analysis of randomized trials. J Am Coll Surg. 2010 Nov;211(5):677-86.

16. LacerdaCF, BertulucciPA, OliveiraATT.Step-by-stepesophagojejunal anastomosisafterintra-corporeal total gastrectomyforlaparoscopic gastric cancer treatment: Techinique of "reverse anvil". Arq Bras Cir Dig. 2014 Jan-Mar;27(1):71-6.
17. Lauren P. the two histological main types of gastric carcinoma: diffuse and so-called intestinal-type carcinoma. an attempt at a histo-clinical classification. ActaPatholMicrobiol Scand. 1965;64:31-49.

18. Lee JH, Han HS, Lee JH. A prospective randomized study comparing open vs laparoscopy-assisted distal gastrectomy in early gastric cancer: early results. SurgEndosc. 2005 Feb;19(2):168-73.

19. Miura S, Kodera Y, Fujiwara M, Ito S, Mochizuki Y, Yamamura Y, et al. Laparoscopy-assisted distal gastrectomy with systemic lymph node dissection: a critical reappraisal from the viewpoint of lymph node retrieval. J Am Coll Surg. 2004 Jun;198(6):933-8.

20. Ohtani H, Tamamori Y, Noguchi K, Azuma T, Fujimoto S, Oba H, et al. Meta-analysis of laparoscopy-assisted and open distal gastrectomy for gastric cancer. J Surg Res. 2011 Dec;171(2):479-85.

21. Orsenigo E, Di Palo S, Tamburini A, Staudacher C. Laparoscopyassisted gastrectomy versus open gastrectomy for gastric cancer: a monoinstitutional Western center experience. SurgEndosc. 2011 Jan;25(1):140-5.

22. Park do J, Han SU, Hyung WJ, Kim MC, Kim W, Ryu SY, et al. Long-term outcomes after laparoscopy-assisted gastrectomy for advanced gastric cancer: a large-scale multicenter retrospective study. SurgEndosc. 2012 Jun;26(6):1548-53.

23. Projeto Acerto [Internet]. c 2010 [citado 2012 Mai 20]. Disponível em: http://www.projetoacerto.com.br/.

24. Sato $H$, Shimada $M$, Kurita $N$, Iwata $T$, Nishioka $M$, Morimoto $\mathrm{S}$, et al. Comparison of long-term prognosis of laparoscopyassisted gastrectomy and conventional open gastrectomy with special reference to D2 lymph node dissection. SurgEndosc. 2012 Aug;26(8):2240-6.

25. Shim JH, Oh SI, Yoo HM, Jeon HM, Park CH, Song KY. Shortterm outcomes of laparoscopic versus open total gastrectomy: a matched-cohort study. The American Journal of Surgery .2013 ; 206:346-51.

26. Shinohara T, Satoh S, Kanaya S, Ishida Y, Taniguchi K, Isogaki J, et al. Laparoscopic versus open D2 gastrectomy for advanced gastric cancer: a retrospective cohort study. SurgEndosc. 2013 Jan;27(1):286-94.

27. Siani LM, Ferranti F, De Carlo A, Quintiliani A. Completely laparoscopic versus open total gastrectomy in stage I-III/C gastric cancer: safety, efficacy and five-year oncologic outcome. Minerva Chir. 2012 Aug; 67(4):319-26.

28. Strong VE, Devaud N, Karpeh M. The role of laparoscopy for gastric surgery in the West. Gastric Cancer. 2009;12(3):127-31.

29. Wei HB, Wei B, Qi CL, Chen TF, Huang Y, Zheng ZH, Huang $J$, Fang JF. Laparoscopic versus open gastrectomy with D2 lymph node dissection for gastric cancer: a meta-analysis. SurgLaparoscEndoscPercutan Tech. 2011 Dec;21(6):383-90.

30. Zhang $X$, Tanigawa N. Learning curve of laparoscopic surgery for gastric cancer, a laparoscopic distal gastrectomy-based analysis. SurgEndosc. 2009 Jun;23(6):1259-64. 